\title{
HUBUNGAN ANTARA FINNISH DIABETES RISK SCORE (FINDRISC) DAN GULA DARAH SEWAKTU (GDS) SEBAGAI PREDIKTOR RISIKO PENYAKIT DIABETES MELLITUS PADA KOMUNITAS BECAK LESTARI SURABAYA
}

\section{Relationship Between Finnish Diabetes, Risk Score (Findrisc) and Blood Sugar at Time (BS) as a Risk Predictor of Mellitus Diabetes In The Becak Community Lestari Surabaya}

\section{Marcellina Rasemi Widayanti}

STIKES Katolik St. Vincentius a Paulo, Surabaya

\section{Riwayat artikel}

Diajukan: 6 Februari 2020

Diterima: 28 Maret 2020

Penulis Korespondensi:

- Marcellina Rasemi Widayanti

- STIKES Pemkab Jombang

marcellina_raswi@yahoo.c o.id

\section{Kata Kunci:}

FINDRISC, Diabetes Melitus, Gula Darah Sewaktu

\section{Abstrak}

Pendahuluan: Diabetes Mellitus (DM) adalah penyakit metabolik yang ditandai oleh hiperglikemia akibat defek pada sekresi insulin, aksi insulin, atau keduanya. Deteksi dini DM penting dilakukan untuk mencegah terjadinya penyakit DM. Salah satu prediktor terjadinya DM adalah Finnish Diabetes Risk Score (FINDRISC). FINDRISC merupakan alat ukur kuesioner yang digunakan untuk mengidentifikasi seseorang terhadap risiko DM Tipe 2. Tujuan dari penelitian ini adalah menganalisis hubungan antara Finnish Diabetes Risk Score (FINDRISC) dan Gula Darah Sewaktu sebagai Prediktor Risiko Diabetes Mellitus pada Komunitas Becak Lestari Surabaya.

Metode: Desain penelitian ini adalah analitik korelasi dengan pendekatan secara crosssectional. Data diambil di komunitas becak Lestari Surabaya pada bulan Oktober November 2019. Teknik pengambilan sampel pada penelitian ini adalah purposive sampling.

Hasil: Total sampel dalam penelitian ini adalah 136 responden. Jenis kelamin dominan dalam penelitian ini adalah perempuan sebanyak 75 responden $(55,1 \%)$ dan usia yang mendominasi dalam rentang 45 - 54 tahun sebanyak 51 responden $(37,5 \%)$ serta rentang usia 55 - 64 tahun sebanyak 51 responden (37,5\%). Hasil uji statistik rank spearman antara FINDRISC score dan hasil pemeriksaan GDS menunjukkan nilai p 0,004 ( $<<0,05)$. Kesimpulan: Ada hubungan antara FINDRISC score dan hasil pemeriksaan GDS

\section{Abstract}

Introduction Diabetes Mellitus (DM) is a metabolic disease characterized by hyperglicemia due to defect in insulin secretionn, insulin action or both. Early detection DM was important to prevent DM. One predictor of DM is Finnish Diabetes Risk Score (FINDRISC). FINRISC is a questionnaire measurement tools that is used to identify a person against the risk of type $2 \mathrm{DM}$. The purpuse of this etudy was to analyzed the relationship between FINDRISC dan blood sugar as a prediction for DM in the Surabaya Becak Community.

Method: The design of this study was analytic correlation with cross sectional approach. The data was taken in the Surabaya Beak Community in October until November 2019. The sampling technique in this study was purposive sampling.

Results: The total sample in this study was 136 respondents. The dominant sex in this study were 75 respondents $(55,1 \%)$ female and the dominant age in the range of $45-54$ years was 51 respondents $(37,5 \%)$ and the range age $55-64$ years was 51 respondents $(37,5 \%)$. Spearman statistical test result between FINDRISC score and blood sugar examination showed $\mathrm{p}$ value $=0,004(\mathrm{p}<0,05)$.

Conclusion: There is a relationship between FINDRISC score and blood sugar examination.
}

\section{PENDAHULUAN}

Diabetes Mellitus (DM) adalah penyakit metabolik yang ditandai oleh hiperglikemia akibat defek pada sekresi insulin, aksi insulin, atau keduanya. Hiperglikemia kronis dari diabetes berhubungan dengan kerusakan jangka panjang, disfungsi, dan kegagalan 
berbagai organ tubuh, terutama mata, ginjal, saraf, jantung, dan pembuluh darah (American Diabetes Association, 2010). Beberapa proses patogenik terlibat dalam perkembangan diabetes. Proses dimulai dari penghancuran autoimun sel-sel pankreas dengan defisiensi insulin hingga kelainan yang mengakibatkan resistensi terhadap insulin. Peningkatan sekresi insulin dan cacat pada aksi insulin sering terjadi bersama pada pasien yang sama, dan sering tidak jelas yang kelainan, jika hanya sendirian, adalah penyebab utama hiperglikemia.

Diabetes menyebabkan 1,5 juta kematian pada tahun 2012. Fenomena ini akan mengakibatkan perkembangan secara progresif terhadap komplikasi Diabetes Mellitus. Gula darah yang lebih tinggi dari batas maksimum mengakibatkan tambahan 2,2 juta kematian, dengan meningkatkan risiko penyakit kardiovaskular dan lainnya. Empat puluh tiga persen (43\%) dari 3,7 juta kematian ini terjadi sebelum usia 70 tahun. Persentase kematian yang disebabkan oleh diabetes yang terjadi sebelum usia 70 tahun lebih tinggi di negara-negara berpenghasilan rendah dan menengah daripada di negara-negara berpenghasilan tinggi. (WHO Global Report, 2016).

Jika dibandingkan dengan tahun 2013, prevalensi DM berdasarkan diagnosis dokter pada penduduk umur $\geq$ 15 tahun hasil Riskesdas 2018 meningkat menjadi 2\%. Prevalensi DM berdasarkan diagnosis dokter dan usia $\geq 15$ tahun yang terendah terdapat di Provinsi NTT, yaitu sebesar $0,9 \%$, sedangkan prevalensi DM tertinggi di Provinsi DKI Jakarta sebesar 3,4\%.Prevalensi DM semua umur di Indonesia pada Riskesdas 2018 sedikit lebih rendah dibandingkan prevalensi DM pada usia $\geq 15$ tahun, yaitu sebesar $1,5 \%$ (Kementerian Kesehatan RI, 2019).

Deteksi dini DM penting dilakukan untuk mencegah terjadinya penyakit DM. Salah satu prediktor terjadinya DM adalah Finnish Diabetes Risk Score (FINDRISC). FINDRISC merupakan alat ukur kuesioner yang digunakan untuk mengidentifikasi seseorang terhadap risiko DM Tipe 2. Skoring ini penting untuk memahami risiko DM, penyebab DM dan dari sudut pandang kesehatan masyarakat, ini mungkin mengindikasikan suatu kebutuhan (Lima-martínez, Arrau and Jerez, 2016). FINDRISC terdiri dari 8 item yaitu usia, Indeks Massa Tubuh (IMT), lingkar perut, riwayat penggunaan obat darah tinggi, riwayat pemeriksaan gula darah yang tinggi, riwayat DM di keluarga, konsumsi sayur atau buah harian, dan aktivitas fisik.

Faktor risiko DM sering dikaitkan dengan gaya hidup, namun jumlah kematian akibat penyakit kardiovaskular dan diabetes cenderung lebih banyak terjadi di negara berkembang dibandingkan dengan negara maju. DM juga menjadi penyebab terjadinya amputasi (yang bukan disebabkan oleh trauma), disabilitas, hingga kematian. Dampak lain dari diabetes adalah mengurangi usia harapan hidup sebesar 510 tahun. Usia harapan hidup penderita DM tipe 2 yang mengidap penyakit mental serius, seperti Skizofrenia, bahkan 20\% lebih rendah dibandingkan dengan populasi umum (Garnita, 2012).

Berdasarkan paparan fenomena DM yang terus meningkat dan risiko komplikasi yang sustematik, maka tujuan dari penelitian ini adalah menganalisis hubungan antara Finnish Diabetes Risk Score (FINDRISC) dan Gula Darah Sewaktu sebagai Prediktor Risiko Diabetes Mellitus pada Komunitas Becak Surabaya.

\section{METODE}

Desain penelitian ini adalah analitik korelasi dengan pendekatan secara crosssectional. Data diambil di komunitas becak Lestari Surabaya pada bulan Oktober - November 2019. Teknik pengambilan sampel pada penelitian ini adalah purposive sampling dengan mengambil sampel yang memiliki karakteristik sesuai dengan kriteria inklusi dan eksklusi penelitian. Inklusi kriteria dari penelitian ini adalah bersedia menjadi 
responden, berusia $\geq 18$ tahun dan responden yang sedang menderita penyakit DM Tipe 2 dijadikan sebagai kriteria eksklusi.

Pengumpulan data dilakukan oleh peneliti setelah mendapat ijin dari Komunitas Becak Lestari Surabaya. Peneliti dan enumerator peneliti memberikan informed consent sebagai wujud kesediaan responden. Peneliti dan enumerator penelitian melakukan pengumpulan data dengan melakukan pemeriksaan GDS, pengisian kuesioner FINDRISC, kuesioner dan hasil pemeriksaan GDS dikumpulkan dan didokumentasikan oleh peneliti

\section{HASIL DAN PEMBAHASAN \\ HASIL}

Responden pada penelitian ini sejumlah 136 orang yang memenuhi kriteria inklusi. Tabel 1. Karakteristik Umum Responden

\begin{tabular}{llcc}
\hline Karakteristik & & Frekwensi & $\%$ \\
\hline Jenis & Laki-laki & 61 & 44,9 \\
Kelamin & Perempuan & 75 & 55,1 \\
Usia & $<45$ tahun & 18 & 13,2 \\
& $45-54$ & 51 & 37,5 \\
& tahun & & \\
& $55-64$ & 51 & 37,5 \\
& tahun & & \\
FINDRISC & $>64$ tahun & 16 & 11,8 \\
score & Rendah & 15 & 11 \\
& & & \\
& Sedikit & 69 & 50,7 \\
& Meningkat & & \\
& Sedang & 34 & 25 \\
& Tinggi & 18 & 13,2 \\
& Sangat & 0 & 0 \\
& Tinggi & & \\
\hline
\end{tabular}

Tabel 1 menunjukkan karakteristik umum responden ini adalah jenis kelamin dominan dalam penelitian ini adalah perempuan sebanyak 75 responden $(55,1 \%)$. Rentang usia dalam penelitian ini 45 - 54 tahun sebanyak 51 responden $(37,5 \%)$ dan $55-64$ tahun sebanyak 51 responden (37,5\%). Kategori FINDRISC score yang mendominasi dalam penelitian ini adalah sedikit meningkat yaitu sebanyak 69 responden $(50,7 \%)$.

Tabel 2 Karakteristik Hasil Pemeriksaan GDS

Tabel 2. Karakteristik hasil pemeriksaan GDS

\begin{tabular}{|c|c|c|c|c|}
\hline Kategori & Mean & Min & Max & SD \\
\hline
\end{tabular}

\begin{tabular}{lllll}
\hline GDS & 155,96 & 62 & 472 & 73,411 \\
\hline
\end{tabular}

Berdasarkan tabel 2, didapatkan hasil rerata pemeriksaan GDS adalah 155,96 $\mathrm{mmHg} \quad(\mathrm{SD} \pm 73,411)$, dengan hasil pemeriksaan minimum adalah $62 \mathrm{mmHg}$ dan maksimum $472 \mathrm{mmHg}$.

Hasil uji statistik rank spearman antara FINDRISC score dan hasil pemeriksaan GDS menunjukkan nilai $\mathrm{p} 0,004(\mathrm{p}<0,05)$, sehingga menunjukkan ada hubungan antara FINDRISC score dan hasil pemeriksaan GDS. Adapun nilai $r=0.242$ menunjukkan korelasi positif dengan kekuatan yang lemah. Hal ini menunjukkan bahwa semakin tinggi nilai FINDRISC maka semakin tinggi pula hasil pemeriksaan GDS.

\section{PEMBAHASAN}

Secara umum, hasil penelitian menunjukkan bahwa kelompok yang mendominasi adalah pada kelompok yang memiliki risiko sedikit meningkat untuk muncul penyakit 1 dari 25 peyakit dan mengalami DM Tipe 2 dalam 10 tahun mendatang. FINDRISC terdiri dari delapan komponen yaitu usia, Indeks Massa Tubuh (IMT), lingkar perut, riwayat penggunaan obat darah tinggi, riwayat pemeriksaan gula darah yang tinggi, riwayat DM di keluarga, konsumsi sayur atau buah harian, dan aktivitas fisik.

Hasil penelitian menunjukkan usia responden menunjukkan pada rentang 45 sampai 54 dan 55-64 tahun mendominasi. Penelitian ADA (2018) menjelaskan bahwa risiko menderita DM Tipe 2 meningkat seiring dengan bertambahnya usia. Seseorang yang berusia lebih dari 45 tahun memiliki risiko menderita DM Tipe sebanyak 9,3 kali dibandingkan dengan orang yang berusia kurang dari 45 tahun (Wicaksono, 2015). Usia menjadi salah satu faktor yang melandasi terjadinya DM Tipe 2 karena adanya peningkatan komposisi lemak dalam tubuh yang terakumulasi pada abdomen yang memicu terjadinya obesitas sentral dan memicu terjadinya retensi insulin.

Komponen FINDRISC kedua adalah Indeks Massa Tubuh (IMT) yang sebagian besar hasil penelitian 
menunjukkan $>30 \mathrm{~kg} / \mathrm{m}^{2}$ sebanyak 51 responden. Menurut Ganz et al. (2014) seseorang yang memiliki berat badan berlebih memiliki risiko menderita DM Tipe 2 1, 5 kali, obesitas derajat I memiliki risiko 2,5 kali, obesitas derajat II memiliki risiko 3,6 kali, dan obesitas derajat III memiliki risiko sebanyak 5,1 kali dibandingkan orang yang memiliki IMT normal. Keadaan berat badan berlebih atau obesitas membuat tubuh mengalami peningkatan asam lemak, penumpukan lemak di intra sel serta pembentukan setokin yang menyebabkan kerusakan fungsi insulin. Proses inflamasi juga dapat terjadi pada keadaan obesitas karena adanya peningkatan setokin yang mengakibatkan induksi respons stres sehingga menyebabkan resistensi insulin. Komponen FINDRISC ketiga adalah lingkar perut. Hasil penelitian menunjukkan ada dua kelompok yang dominan yaitu kelompok lingkar perut 94 sampai 102 sebanyak 45 responden dan lebih dari $102 \mathrm{~cm}$ sebanyak 45 responden. Lingkar perut sering dikaitkan dengan penumpukan lemak sentral dan memicu terjadinya penurunan fungsi insulin. Komponen keempat adalah riwayat penggunaan obat darah tinggi. Hipertensi merupakan faktor risiko vaskular yang utama pada diabetes usia lanjut. Komponen kelima adalah riwayat pemeriksaan gula darah yang tinggi, komponen keenam adalah riwayat DM di keluarga. Keluarga yang mengalami DM dapat menurunkan faktor genetik kepada keluarga lainnya. Komponen ketujuh adalah konsumsi sayur atau buah harian. Perubahan pola makan dan pengaturan makan memegang peranan penting dalam upaya pengendalian kadar gula darah pada pasien DM. Salah satu manfaat yang diperoleh penderita DM dalam pengaturan makan adalah dapat meningkatkan sensitifitas reseptor insulin sehingga akhirnya dapat menurun- kan kadar glukosa darah (Dewi, 2014). Komponen kedelapan adalah aktivitas fisik. Aktivitas fisik/olahraga bertujuan untuk mengendalikan kadar gula darah, karena latihan jasmani yang teratur menyebabkan kontraksi otot meningkat dan resistensi insulin berkurang. Aktivitas fisik/ olahraga dapat menyebabkan terjadinya peningkatan pemakaian glukosa oleh otot yang aktif, sehingga secara langsung olahraga dapat menyebabkan penurunan glukosa darah (Hariyanto, 2013).

Hasil penelitian menunjukkan Gula Darah Sewaktu (GDS) responden komunitas becak Surabaya reratanya adalah 155, 96 mg/dl. Gula Darah Sewaktu merupakan kondisi glukosa seseorang saat pemeriksaan. Gula Darah dapat meningkat setelah mengkonsumsi makanan, jarang aktivitas fisik dan kegemukan. Hasil ini sesuai dengan penelitian sebelumnya yang meneliti perbedaan antara gula darah pria dewasa muda obesitas dengan pria dewasa muda normal dimana pada hasil penelitian tersebut juga didapatkan peningkatan kadar gula darah puasa pada pria dewasa yang obesitas.

Hasil pemeriksaan ini juga mendukung teori bahwa kegemukan dan distribusi lemak dapat mengubah metabolisme glukosa dan terjadinya insulin resisten. Seseorang dengan aktivitas fisik ringan akan berisiko untuk peningkatan kadar gula darah dibandingkan orang yang memiliki aktivitas fisik berat. Aktivitas fisik dapat menyebabkan peningkatan kadar gula darah melalui 2 cara, yakni dengan kurangnya aktivitas fisik maka penumpukan jaringan lemak akan semakin tinggi yang dapat menyebabkan resistensi insulin dan kurangnya aktivitas fisik juga dapat menyebabkan pengurangan kemampuan jaringan menerima insulin (Auliya, Oenzil and Rofinda, 2016).

Peningkatan kadar glukosa darah disebabkan karena terganggunya homeostasis pengaturan glukosa darah. Gangguan pengaturan glukosa darah pada lansia meliputi tiga hal yaitu resistensi insulin, hilangnya pelepasan insulin fase pertama, dan peningkatan kadar glukosa darah postprandial, diantara ketiga gangguan tersebut yang paling berperan adalah resistensi insulin. 
Hasil penelitian menunjukkan ada hubungan antara FINDRISC dengan GDS. Banyak hal yang mempengaruhi kadar gula darah sewaktu yang berisiko meningkatkan prevalensi terjadinya penyakit DM diantaranya adalah riwayat keluarga, pola makan, usia, IMT, tingkat pendididkan, pekerjaan, aktivitas fisik, terpapar asap dan tekanan darah (Isnaini and Ratnasari, 2018).

Orang dengan latar belakang keluarga yang memiliki satu atau lebih anggota keluarga dengan ibu, ayah ataupun keluarga yang terkena DM akan mempunyai peluang kejadian 2 sampai 6 kali lebih besar berpeluang terjadi diabetes dibandingkan dengan orang yang tidak memiliki keturunan penyakit DM (CDC, 2011). Risiko untuk mendapatkan DM dari ibu lebih besar 10-30\% dari pada ayah dengan DM. Hal ini dikarenakan penurunan gen sewaktu dalam kandungan lebih besar dari ibu. Jika saudara kandung menderita DM maka risiko untuk menderita DM adalah 10\% dan 90\% jika yang menderita adalah saudara kembar identik (Diabetes UK, 2010).

Aktifitas fisik dan olahraga rutin dapat mempengaruhi aksi insulin dalam metabolisme glukosa dan lemak pada otot rangka. Aktifitas fisik akan menstimulasi penggunaan insulin dan pemakaian glukosa dalam darah serta dapat meningkatkan kerja otot. Adaptasi fisiologis meliputi peningkatan pasokan kapiler ke otot skeletal, peningkatan aktifitas enzim dari ranta transpor elektron mitokondria, dan peningkatan secara bersamaan pada volume dan kepadatan mitokondria. Aktifitas fisik yang teratur dapat berperan dalam mencegah risiko DM dengan meningkatkan massa tubuh tanpa lemak dan secara bersamaan mengurangi lemak tubuh. Aktifitas fisik mengakibatkan insulin semakin meningkat sehingga kadar gula dalam darah akan berkurang (Wicaksono, 2015). Orang yang jarang beraktifitas fisik dan jarang melakukan olahraga, zat makanan yang masuk ke dalam tubuh tidak akan dibakar tetapi akan ditimbun dalam bentuk lemak dan gula. Jika kondisi pankreas tidak adekuat dalam menghasilkan insulin dan tidak mencukupi untuk mengubah glukosa menjadi energi maka akan timbul penyakit DM.

Faktor usia mempengaruhi penurunan pada semua sistem tubuh, tidak terkecuali sistem endokrin. Penambahan usia menyebabkan kondisi resistensi pada insulin yang berakibat tidak stabilnya level gula darah sehingga banyaknya kejadian DM salah satu diantaranya adalah karena faktor penambahan usia yang secara degenerative menyebabkan penurunan fungsi tubuh. Perempuan lebih berpeluang untuk terjadi DM dibandingkan laki laki dengan alasan faktor hormonal dan metabolisme. Perempuan mengalami siklus bulanan dan menopouse yang berkontribusi terhadap peningkatan jumlah lemak tubuh menjadi sangat mudah terakumulasi akibat proses tersebut sehingga perempuan lebih berisiko terkena penyakit DM tipe dua (Irawan, 2010). Aktivasi dari ekspresi gen ER dan ER yang kondisi ini menyebabkan sensitivitas insulin dan pengambilan gula jugaakan turun, sehingga gula akan menumpuk dalam bentuk lemak dalam tubuh yang dapat mengakibatkan obesitas.

Tekanan darah yang tinggi dapat menyebabkan pendistribusian gula pada sel tidak berjalan optimal sehingga akan terjadi akumulasi gula dan kolesterol dalam darah. Sebaliknya jika kondisi tekanan darah berada pada rentang normal maka gula darah akan terjaga dalam rentang normal karena insulin bersifat sebagai zat pengendalian dari sistem renin dan angiotensin. Kadar insulin yang cukup menyebabkan tekanan darah terjaga, tekanan darah diatas 120/90 $\mathrm{mmHg}$ memiliki risiko diabetes dua kali lipat dibandingkan dengan orang yang tekanan darahnya normal (Brunner and Suddarth, 2013). Penelitian ini memiliki keterbatasan yaitu tidak tidak dilakukan observasi atau pengukuran GDS sebelum penelitian, dan setelah penelitian.

\section{KESIMPULAN}


Berdasarkan hasil penelitian dapat disimpulkan bahwa FINDRISC score memiliki hubungan degan hasil pemeriksaan GDS dengan korelasi positif yang menunjukkan semakin tinggi nilai FINDRISC maka nilai GDS juga semakin tinggi. Nilai FINDRISC yang tinggi dapat memprediksi berbagai penyakit yang dapat timbul terutama penyakit DM Tipe 2 dalam 10 tahun mendatang.

\section{DAFTAR PUSTAKA}

American Diabetes Association. (2010). DEFINITION AND DESCRIPTION OF DIABETES OTHER CATEGORIES OF GLUCOSE. Diabetes Care, 33. doi: $10.2337 / \mathrm{dc} 10-\mathrm{S} 062$

Auliya, P., Oenzil, F. and Rofinda, Z. D. (2016). Artikel Penelitian Gambaran Kadar Gula Darah pada Mahasiswa Fakultas Kedokteran Universitas Andalas yang Memiliki Berat Badan Berlebih dan Obesitas . Jurnal Kesehatan Anadalas, 5(3), pp. 528-533. Available at: http:' 'jurnal.fk.unand.ac.id.

Brunner and Suddarth. (2013). Buku Ajar Keperawatan Medikal Bedah. Edisi 8 Volume 1. Jakarta: EGC

CDC. (2011). Family History as a Tool for Detecting Children at Risk for Diabetes and Cardiovascular Disease.

Dewi, E. (2014). Gambaran Faktor-Faktor Yang Mempengaruhi Terkendalinya Kadar Gula Darah Pada Pasien Diabetes Mellitus Di puskesmas Pakis Surabaya. Surabaya: AKPER.

Diabates UK. (2010). Diabetes in the UK 2010: Key Statistics on Diabetes

Ganz ML, Wintfield N, Li Q, Alas V, Langer J, Hammer M. (2014). The Association of Body Mass Index with the Risk of Type 2 Diabetes: A case control study nested in a Electronic Health Records System in The United States. Diabetology \& Metabolic Syndrome, 6(50)

Garnita, Dita. (2012). Faktor Resiko Diabetes Melitus (Analisis Data Sakerti 2007).Skripsi. Universitas Indonesia

Hariyanto, F. (2013). Hubungan Aktivitas Fisik Dengan Kadar Gula Darah Puasa Pada Pasien Diabetes Mellitus Tipe 2 Di RSD Kota Cilegon. Jakarta: FK.

Irawan, Dedi. 2010. Prevalensi Faktor Risiko Kejadian Diabetes Melitus Tipe 2 di Daerah Urban Indonesia (Analisa Data Sekunder Riskesdas 2007). Thesis. Universitas Indonesia

Isnaini, N. and Ratnasari. (2018). Faktor risiko mempengaruhi kejadian Diabetes mellitus tipe dua Risk factors was affects of diabetes mellitus type 2. Jurnal Keperawatan dan Kebidaan Aisiyah, 14(1), pp. 59-68.

Kementerian Kesehatan RI. (2019). HARI DIABETES SEDUNIA TAHUN 2018. Jakarta.

Lima-martínez, M. M., Arrau, C. and Jerez, S. (2016). Relationship between the Finnish Diabetes Risk Score ( FINDRISC), vitamin D levels , and insulin', Primary Care Diabetes. Primary Care Diabetes Europe, pp. 1-7. doi: 10.1016/j.pcd.2016.11.001.

WHO. 2016. Country and Regional Data on Diabetes, WHO South East Asia Region

http://www.WHO.org/Countryand regional-data-on-diabetes (diakses tanggal 16 agustus 2019)

Wicaksono RP. 2015. Faktor - faktor yang berhubungan dengan kejadian DM Tipe 2. Semarang: UNDIP 